\title{
Comparison of Hydration Properties of Cement-Carbon Steel Slag and Cement-Stainless Steel Slag Blended Binder
}

\author{
Saly Fathy $\mathbb{D}^{1},{ }^{1}$ Guo Liping $\mathbb{D}^{1,},{ }^{1,2,3}$ Rui Ma, ${ }^{1}$ Gu Chunping $\mathbb{D}^{4},{ }^{4}$ and Sun Wei ${ }^{1,2,3}$ \\ ${ }^{1}$ School of Material Science and Engineering, Southeast University, Nanjing 211189, China \\ ${ }^{2}$ Collaborative Innovation Center for Advanced Civil Engineering Materials, Nanjing 211189, China \\ ${ }^{3}$ Jiangsu Key Laboratory of Construction Materials, Nanjing 211189, China \\ ${ }^{4}$ College of Civil Engineering and Architecture, Zhejiang University of Technology, Zhejiang 310014, China \\ Correspondence should be addressed to Saly Fathy; salsol313@yahoo.com
}

Received 11 April 2018; Accepted 11 June 2018; Published 10 July 2018

Academic Editor: Shazim A. Memon

Copyright (C) 2018 Saly Fathy et al. This is an open access article distributed under the Creative Commons Attribution License, which permits unrestricted use, distribution, and reproduction in any medium, provided the original work is properly cited.

\begin{abstract}
This article investigates the effect of carbon steel slag (CS) and stainless steel slag (SS) on the hydration of cement (OPC). Two slags were used to replace cement at a replacement ratio of 15\% (CS15 and SS15) and 30\% (CS30 and SS30), respectively, by binder weight. Test results demonstrated that the hydration rate of OPC-CS binder is similar to that of OPC-SS binder at 3 days but higher than the latter at later ages. The negative effect of steel slag (CS) on the strength of cement mortar can be neglected when its replacement ratio does not exceed 15\%. X-ray diffraction (XRD) and thermogravimetry (TG) show that the incorporation of SS tends to decrease calcium hydroxide $(\mathrm{CH})$ content more than the incorporation of CS in the cement matrix. BSE (backscattered electron)/EDX (energy-dispersive X-ray spectroscopy) analyses estimate the average Si/Ca ratio of CS30 and SS30 at 90 days to be $0.41(\mathrm{Ca} / \mathrm{Si}=2.44)$ and $0.45(\mathrm{Ca} / \mathrm{Si}=2.22)$, respectively, compared to $0.43(\mathrm{Ca} / \mathrm{Si}=2.33)$ for pure cement.
\end{abstract}

\section{Introduction}

As a key ingredient of concrete, cement with its huge production flows causes significant societal and environmental impacts. Cement production is contributing to about $5 \%-8 \%$ of global carbon dioxide $\left(\mathrm{CO}_{2}\right)$ emissions [1]. More emphasis has to be given to increase the utilization ratio of waste industry by-products to replace cement during concrete production. Carbon steel slag and stainless steel slag are the by-products of iron and steel production. Large amounts of steel slags are released every year that also occupies farmlands and consequently leads to serious pollution risks $[2,3]$. Therefore, the utilization of steel slags as mineral admixture can develop the ecological consciousness of both cement and steel production sectors. Generally, it is believed that the major active minerals of steel slags as well as cement are clinker minerals represented in calcium silicates $[4,5]$. However, the low cooling and relatively high proportion of inert phases of steel slag is considered the main causes of its poor activity compared to cement [6]. The predominant mineral components of steel slag are $\mathrm{C}_{3} \mathrm{~S}$ and $\mathrm{C}_{2} \mathrm{~S}[7,8]$. Different literatures have studied the possibility of using steel slag after grinding it to fine powder as a cementitious material [9, 10]. Wang et al. [6] reported that fine steel slag with particle sizes smaller than $20 \mu \mathrm{m}$ possesses relatively good cementitious properties, and its influence on the porosity of paste and the strength of mortar is negligible when its replacement ratio is not more than $20 \%$. Liu and Li [11] found that increasing steel slag fineness enhanced its early exothermic rate and increased early hydration heat and nonevaporable water content. Furthermore, they observed that blended cement mortar containing finer steel slag gains higher 28-day strength. Wang et al. [12] found that steel slag decreases the early hydration rate of cement but improve and promote the hydration of cement at later ages.

In the case of stainless steel slag, only $\beta-\mathrm{C}_{2} \mathrm{~S}$ poses stainless steel slag activity $[7,13,14]$. However, the mechanical activation of stainless steel slag has been studied to be a possible way to increase its hydraulic activity $[7,15]$. Sheen et al. [7] proved that the higher fineness stainless steel 
TABle 1: The chemical composition of CS and SS.

\begin{tabular}{|c|c|c|c|c|c|c|c|c|c|c|c|c|c|c|}
\hline Type & $\mathrm{SiO}_{2}$ & $\mathrm{CaO}$ & $\mathrm{MgO}$ & $\mathrm{Fe}_{2} \mathrm{O}_{3}$ & $\mathrm{Al}_{2} \mathrm{O}_{3}$ & $\mathrm{TiO}_{2}$ & $\mathrm{SO}_{3}$ & $\mathrm{P}_{2} \mathrm{O}_{5}$ & $\mathrm{Cr}_{2} \mathrm{O}_{5}$ & $\mathrm{MnO}$ & $\mathrm{K}_{2} \mathrm{O}$ & $\mathrm{Na}_{2} \mathrm{O}$ & $\mathrm{ZnO}$ & Loss of ignition \\
\hline OPC & 22.36 & 57.21 & 3.10 & 3.66 & 7.73 & - & 3.54 & - & - & - & - & 0.73 & - & 2.31 \\
\hline CS & 13.40 & 37.50 & 4.61 & 23.82 & 9.90 & 0.84 & 0.78 & 0.87 & 0.02 & 3.52 & 0.36 & 0.25 & 0.85 & 3.28 \\
\hline SS & 27.82 & 43.22 & 5.50 & 8.54 & 4.70 & 0.59 & 1.73 & 0.14 & 0.95 & 2.00 & 0.25 & 0.21 & 0.55 & 3.88 \\
\hline
\end{tabular}

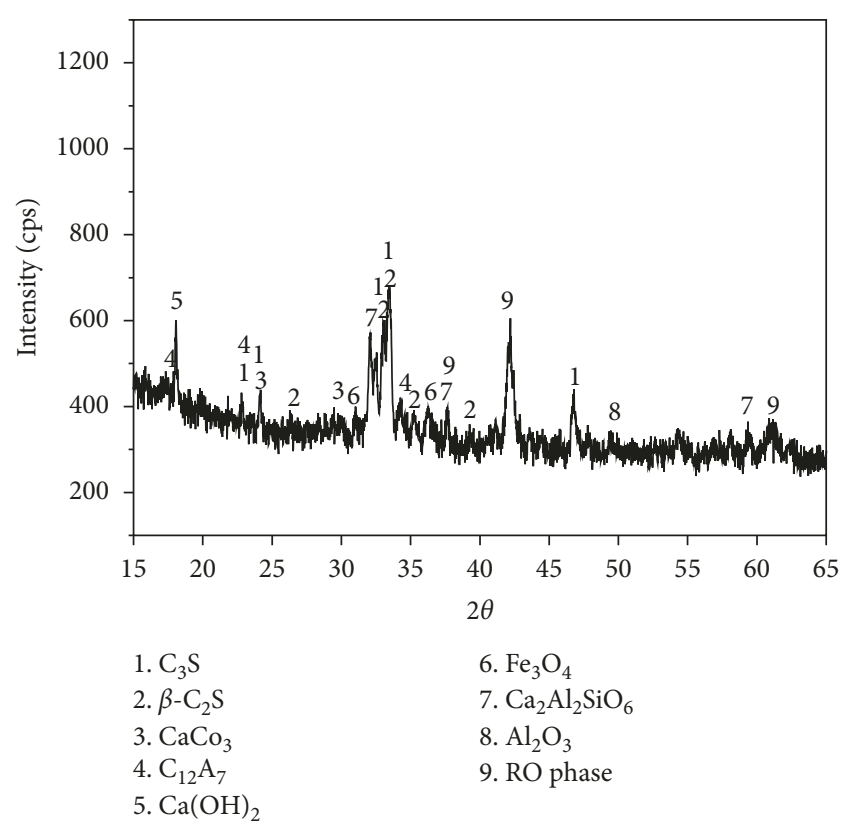

(a)

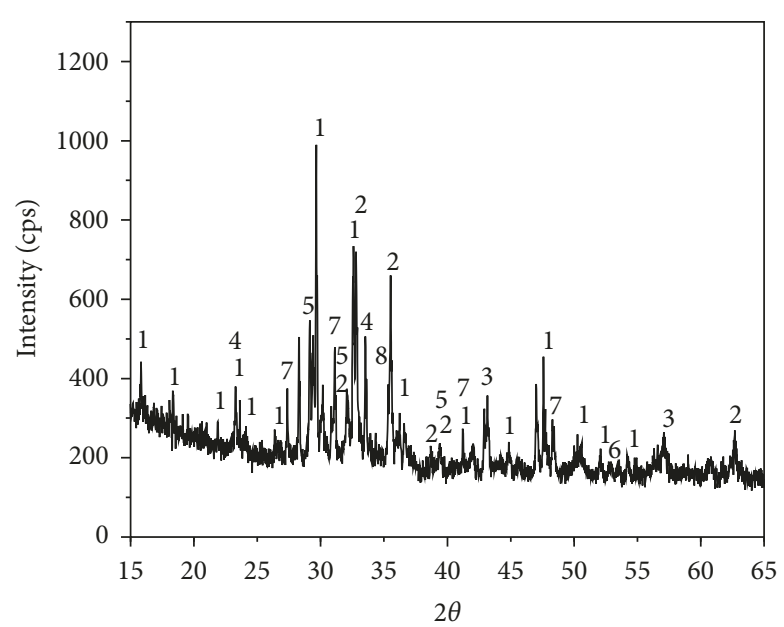

$$
\begin{aligned}
& \text { 1. } \gamma-\mathrm{C}_{2} \mathrm{~S} \\
& \text { 2. } \beta-\mathrm{C}_{2} \mathrm{~S} \\
& \text { 3. } \mathrm{RO} \text { phase } \\
& \text { 4. } \mathrm{Ca}_{3} \mathrm{Si}_{2} \mathrm{O}_{7}
\end{aligned}
$$

5. $\mathrm{CaCO}_{3}$ 6. $\mathrm{Ca}_{12} \mathrm{Al}_{14} \mathrm{O}_{32} \mathrm{~F}_{2}$ 7. $\mathrm{Ca}_{4} \mathrm{Si}_{2} \mathrm{O}_{7} \mathrm{~F}_{2}$ 8. $\mathrm{Fe}_{3} \mathrm{O}_{4}$

(b)

FIgURE 1: The mineralogical composition of CS (a) and SS (b).

slag of $4400 \mathrm{~cm}^{2} / \mathrm{g}$ exhibits stronger engineering properties. Kriskova et al. [15] stated that the mechanical activation of stainless steel slag by intensive milling is a possible way to increase its reactivity to be utilized as a hydraulic binder. In another study, Kriskova et al. [16] investigated that the hydration of mechanically activated $\gamma-\mathrm{C}_{2} \mathrm{~S}$ as a main phase in stainless steel slag, which resulted in the formation of C-S-H gel that is typically formed during the hydration of cement.

It should be noted that the composition of steel slag might be different from that of stainless steel slag, which consequently will affect its hydraulic properties. Although several studies report about the valorization of the hydraulic properties of carbon steel slag or stainless steel slag one at a time, the difference in the behavior between the two materials as a binder compared to each other is still unexplored. Within this context, this study is aimed at investigating the influence of carbon steel slag and stainless steel slag with high fineness on the microstructure and the mechanical properties of cement. Such investigations shall be beneficial for increasing the utilization ratio of these two by-products.

\section{Materials and Test Method}

The cement used was ordinary Portland cement (OPC), which complies with the Chinese National Standard GB1752007 with strength grade of 42.5 and specific surface area of
$3500 \mathrm{~cm}^{2} / \mathrm{g}$. The basic-oxygen-furnace carbon steel slag (CS) with relatively high alumina content and the electric arcfurnace stainless steel slag (SS) used in this study were obtained from Ma Gang Steel Slag Ltd., Ma An Shan, China. The raw CS and SS slags were weathered naturally under laboratory conditions. The specific surface areas of the CS and SS powders are approximately 4515 and $4990 \mathrm{~cm}^{2} / \mathrm{g}$. The soundness of both CS and SS tested by means of (Le Chatelier's) apparatus was less than $5 \mathrm{~mm}$. The oxide composition of OPC, CS, and SS was determined by XRF analysis (Table 1). The mineralogical content for the raw CS and SS, Figure 1, as well for the pulverized hydrated samples after different hydration ages was determined by X-ray diffraction (D8 Discover, Burker-AXS, Germany).

CS and SS replaced cement by $15 \%$ and $30 \%$ and denoted by CS15, CS30, SS15, and SS30, respectively. Water tap was used to prepare the slag pastes at a water-to-slag ratio of 0.3 , which was detected by trials until a standard paste consistency was obtained, and then, they were casted into plastic centrifuge tubes. At the testing age, the hydration of slag pastes was stopped by soaking them in acetone for a specific period. The samples were dried in the oven at $60^{\circ} \mathrm{C}$ for three days before testing. Mortars of $40 \times 40 \times 160 \mathrm{~mm}$ were prepared by mixing paste with sand at the sand-to-paste ratio of 3.0 and denoted by MC, MCS1, MCS2, MSS1, and MSS2. Both the paste and mortar were cured at the temperature of $20 \pm 1^{\circ} \mathrm{C}$. 


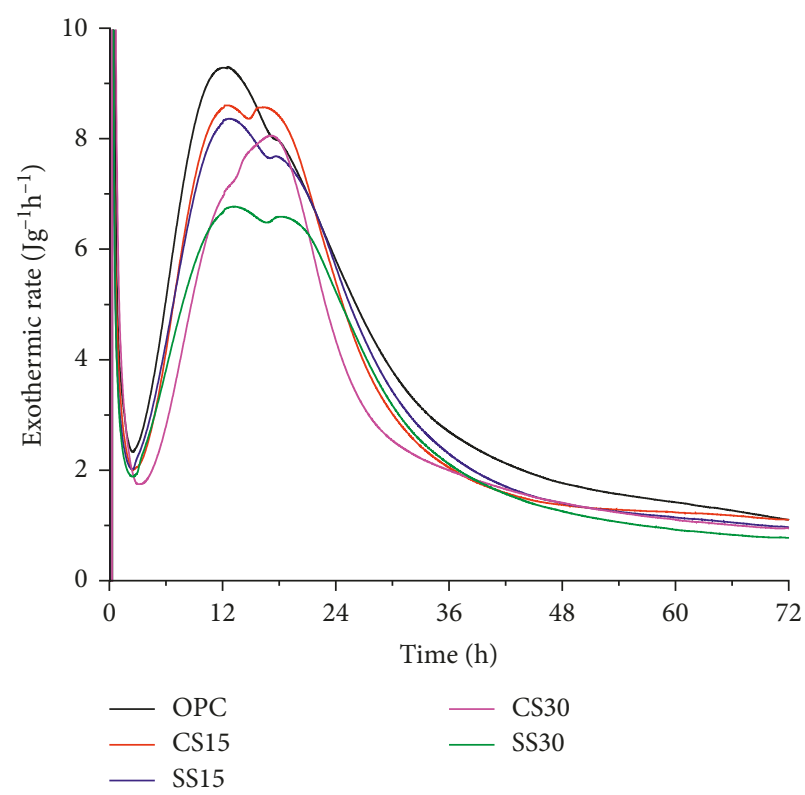

(a)

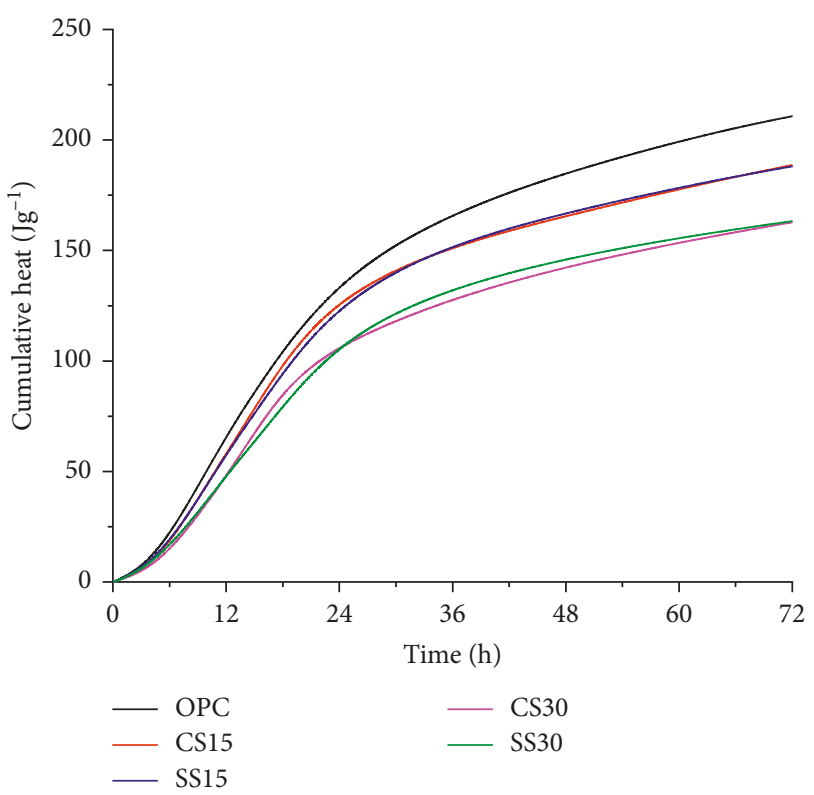

(b)

FIgURE 2: Hydration heat of different slag binders within 3 days: (a) exothermic rate and (b) cumulative hydration heat.

The compressive strength was conducted according to Chinese National Standard GB/T50081-2002.

The rate of heat evolution of slags during the early age of three days was monitored by an isothermal calorimeter (TAM AIR, USA), under a constant temperature of $20^{\circ} \mathrm{C}$. Slag samples were subjected to thermal analysis using TGA/DSC [NETZSCH STA449 F3] at a heating rate of $10^{\circ} \mathrm{C} / \mathrm{min}$, over a temperature range of $20-1000^{\circ} \mathrm{C}$ with nitrogen at a flow rate of $30 \mathrm{~cm}^{3} / \mathrm{min}$. The nonevaporable water $\left(W_{\mathrm{n}}\right)$ content of hardened paste was obtained from the mass difference between the sample dried at $105^{\circ} \mathrm{C}$ and heated at $1000^{\circ} \mathrm{C}$ corrected for the loss from the ignition of the unhydrated sample. The microstructure morphologies of the hydrated slags at different ages were studied using an ESEM (FEI quanta 3D FEG, USA). Polished slag samples hydrated at $90 \mathrm{~d}$ were scanned with secondary electron (SE) in the electron microscope (FEI quanta 3D FEG, USA) with a complementation of EDX elemental mapping and backscattered electron (BSE) with applied electron energy of $15 \mathrm{kV}$.

\section{Results and Discussion}

3.1. Hydration Heat of Cement and Cement Containing Slag. Figure 2 shows the exothermic rates and the cumulative hydration heat of OPC, CS15, CS30, SS15, and SS30 complex binders during the early hydration within $72 \mathrm{~h}$. As expected, replacing cement by CS or SS tends to decrease its hydration heat; the decreasing rate gets higher when higher increment ratios of slags are added. However, the effect of SS compared to CS is more obvious for declining hydration heat at the acceleratory period of the exothermic reaction. Replacing cement by CS seems to drastically increase the rate of heat evolution during the third exothermic peak and its intensity increases with the increment of the amount of CS.

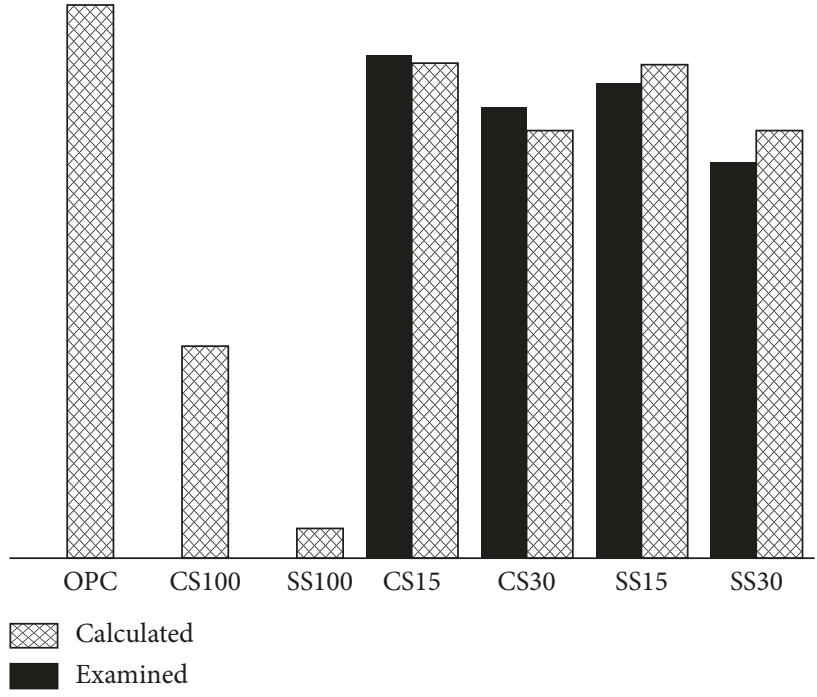

FIgURE 3: The examined and the calculated cumulative heat for different slag binders.

The dominant reaction during this peak seems to be related to CS reaction. It may have been associated with two possible explanations: (1) the conversion of AFt to AFm phase after the complete depletion of gypsum, especially after increasing the ratio of the available alumina to sulfate (gypsum) due to replacing cement by high alumina CS; and (2) the formation of hydrated calcium silicate $(\mathrm{CSH})$, aluminate $(\mathrm{CAH})$, and aluminosilicate (CASH) hydrates.

It can be observed that the cumulative hydration heat for cement-CS and cement-SS are close to each other at the same replacement ratio, Figure 2(b).

Figure 3 shows the examined cumulative heat as well as the calculated cumulative heat for different slag binders. 


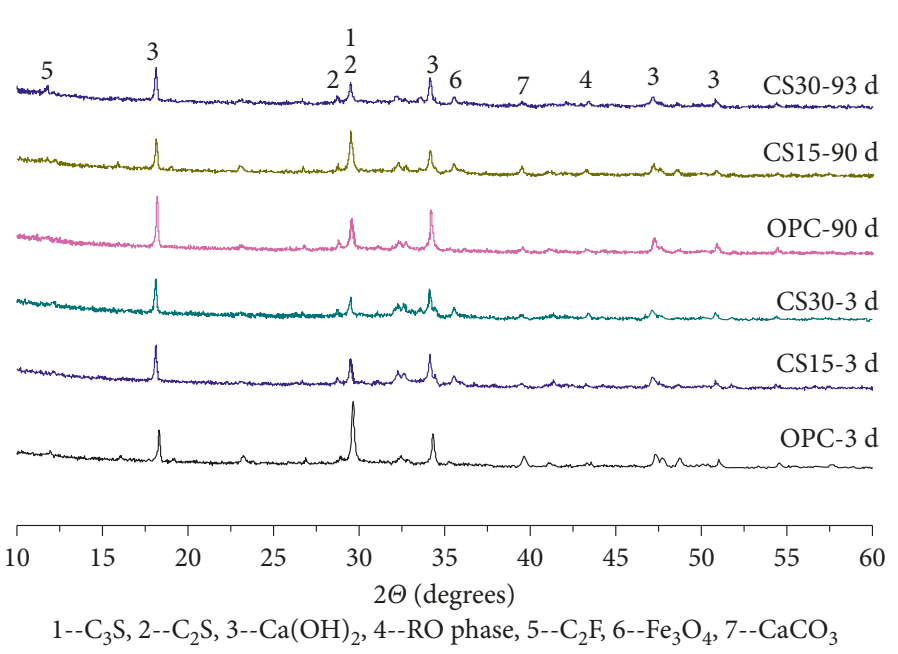

(a)

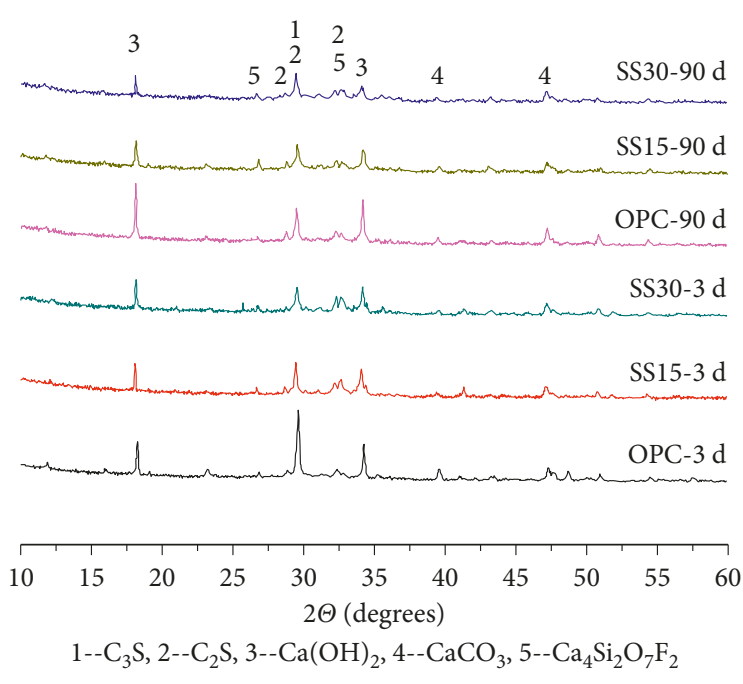

(b)

FIGURE 4: XRD at 3 days and 90 days: (a) OPC, CS15, and CS30; (b) OPC, SS15, and SS30.

For this purpose, the cumulative heat of hydration for pure cement (OPC), pure CS (CS100), and pure SS (SS100) was studied within the same period of $72 \mathrm{~h}$, which was found to be $211 \mathrm{Jg}^{-1}, 80.8 \mathrm{Jg}^{-1}$, and $11.7 \mathrm{Jg}^{-1}$, respectively. The calculated cumulative heats were determined according to the replacement ratios and hydration heats of pure cement and pure slags. Referring to the calculated hydration heat, the examined hydration heats of CS15 and CS30 are $1.36 \%$ and $5.19 \%$, respectively, and lower than the calculated reference. In the opposite, the examined hydration heats of SS15 and SS30 are $3.98 \%$ and $8.13 \%$, respectively, and higher than the calculated reference. It can be concluded that replacing cement with CS tends to hinder the hydration heat of each other at early ages. However, replacing cement with SS conversely shows a promoting effect on the hydration heat of complex binder, indicating that cement and SS might promote the early hydration of each other. Furthermore, the hindering and promoting effects of CS and SS, respectively, are more obvious with the increment of its added amount.

3.2. X-Ray Diffraction (XRD). Figures 4(a) and 4(b) shows the hydration products of cement-CS and cement-SS, respectively, compared to pure cement at different slag proportions at 3 and 90 days. In spite of slag type, the main visible hydration product in XRD pattern for both pure cement and cement-slag complex binder is calcium hydroxide $(\mathrm{CH})$. For the samples containing CS, the peaks corresponding to the unhydraulic phases as RO phase and $\mathrm{C}_{2} \mathrm{~F}$ extruded with the increment of the replacement ratio of slag that did not show changes with age. Furthermore, as an indication of the dilution effect caused by replacing cement with slag that has lower activity, for both cement and slag binders, it was observed that there was a decrease in the peak intensity of the main hydraulic phases as $\mathrm{C}_{3} \mathrm{~S}$ and $\mathrm{C}_{2} \mathrm{~S}$ compared to pure cement. Consequently, it was observed as a decrease in the intensity of $\mathrm{CH}$ peak for both CS- and SS-blended cement especially at higher slag proportions.
What's more, the observed decrease in $\mathrm{CH}$ in SS matrix is mainly due to that $\mathrm{C}_{2} \mathrm{~S}$ is the main cementitious phase of SS. It is well known that $\mathrm{C}_{2} \mathrm{~S}$ produces $\mathrm{CH}$ with much less content than that produced by $\mathrm{C}_{3} \mathrm{~S}$ [17] as a predominant phase in CS. Generally, 1 mole of $\mathrm{C}_{2} \mathrm{~S}$ approximately produces 0.5 mole of $\mathrm{CH}$, but 1 mole of $\mathrm{C}_{3} \mathrm{~S}$ approximately generates 1.5 mole of $\mathrm{CH}$ as shown below:

$$
\begin{aligned}
& \mathrm{C}_{2} \mathrm{~S}+2 \mathrm{H}=0.5 \mathrm{C}_{3} \mathrm{~S}_{2} \mathrm{H}_{3}+0.5 \mathrm{CH} \\
& \mathrm{C}_{2} \mathrm{~S}+3 \mathrm{H}=0.5 \mathrm{C}_{3} \mathrm{~S}_{2} \mathrm{H}_{3}+1.5 \mathrm{CH}
\end{aligned}
$$

3.3. Nonevaporable Water Content $\left(W_{n}\right)$. Figures $5(\mathrm{a})$ and 5(b) show the TG curves of the hydration products of samples OPC, CS15, CS30, SS15, and SS30 pastes at the ages of 3 and 90 days. It can be seen that the mass loss decreased with the increasing of slag proportion especially in the case of SS; this can be regarded as an indication of the decrease in hydration products within three main steps [18]: decomposition of $\mathrm{C}-\mathrm{S}-\mathrm{H}$ gel and hydrated aluminate phases $\left(50-200^{\circ} \mathrm{C}\right)$; decomposition of $\mathrm{Ca}(\mathrm{OH})_{2}\left(400-550^{\circ} \mathrm{C}\right)$ and further decomposition of $\mathrm{CaCO}_{3}\left(550-800^{\circ} \mathrm{C}\right)$.

The nonevaporable water $\left(W_{\mathrm{n}}\right)$ content of hardened paste was obtained from the mass difference between the sample dried at $105^{\circ} \mathrm{C}$ and heated at $1000^{\circ} \mathrm{C}$ corrected by the loss of ignition of the unhydrated sample. Figure 6 shows $W_{\mathrm{n}}$ detected from TG test of the cement-slag pastes at 3 and 90 days. Despite the slag type, it can be observed that $W_{\mathrm{n}}$ decreases with increasing slag proportion. Furthermore, $W_{\mathrm{n}}$ for SS was lower than that for CS at the same replacement ratios at all ages.

3.4. $\mathrm{Ca}(\mathrm{OH})_{2}$. For pure cement, calcium hydroxide $(\mathrm{CH})$ content increases with increasing curing age. Therefore, the amount of $\mathrm{CH}$ present is directly proportional to the amount of cement. The determination of $\mathrm{CH}$ content is performed according to the following formula [19]: 


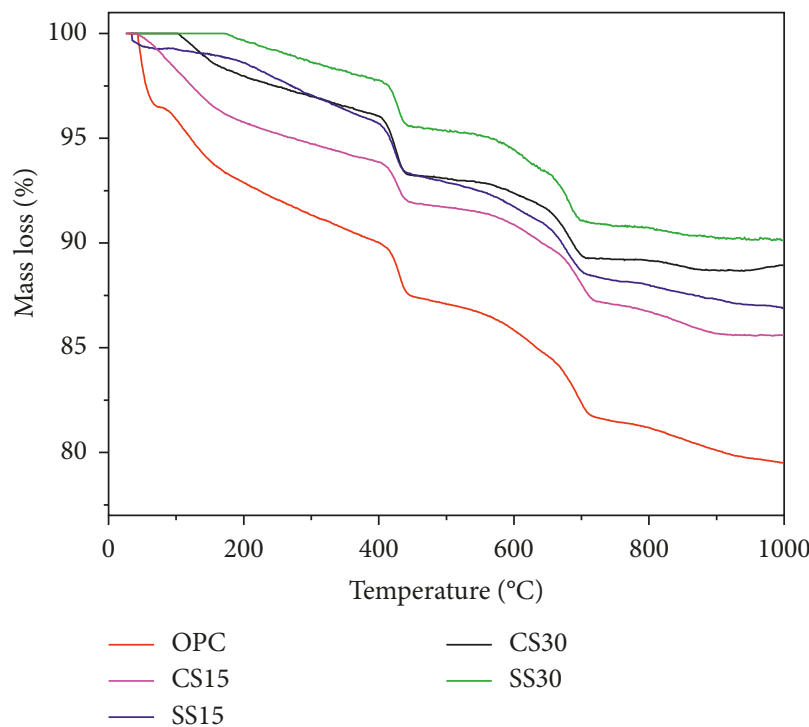

(a)

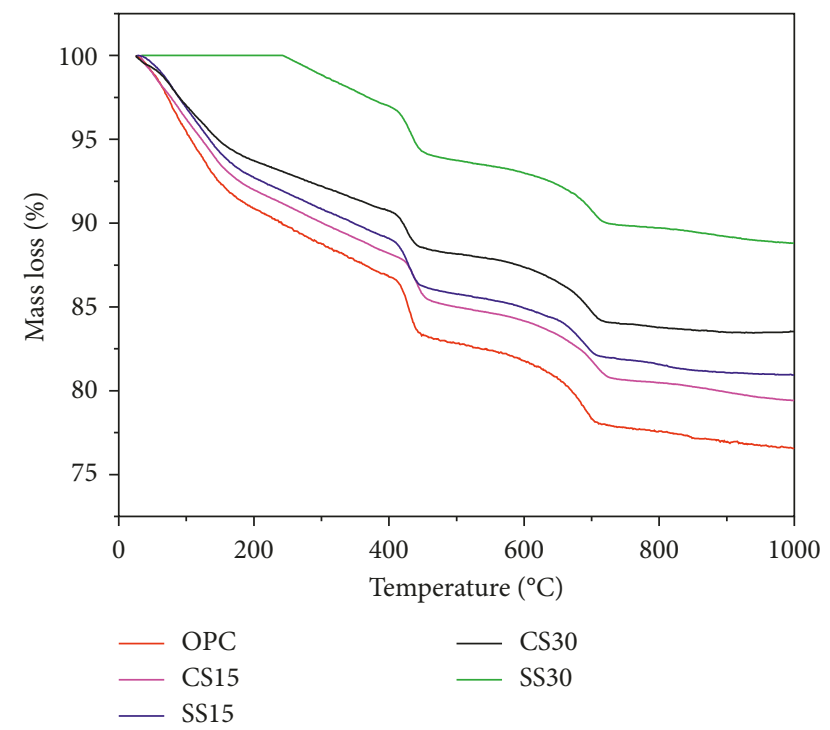

(b)

FIgure 5: The TG curves of the hydration products of OPC, CS15, CS30, SS15, and SS30 (a) at 3 days and (b) at 90 days.

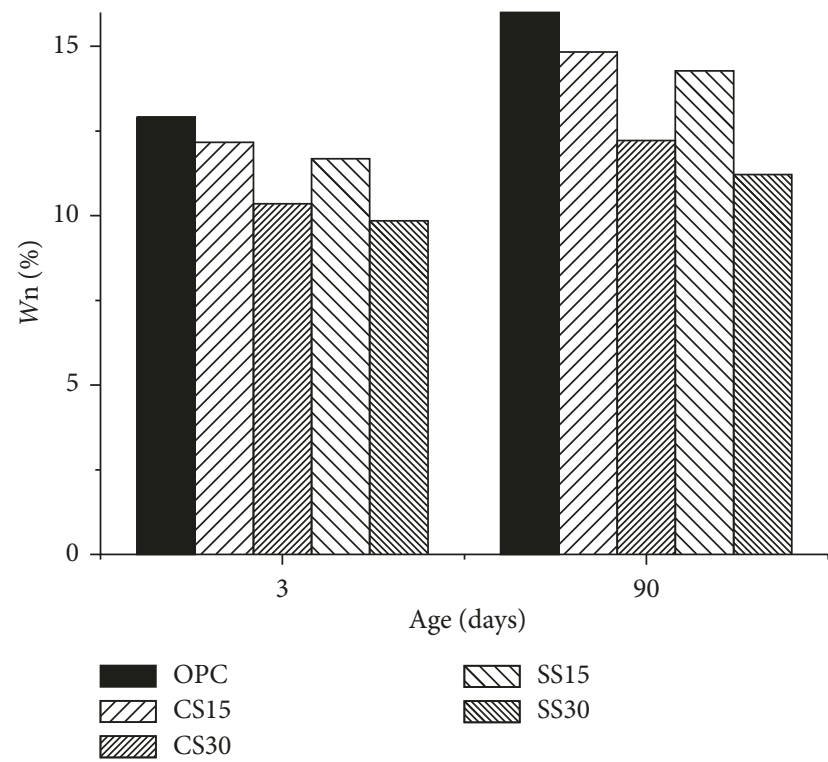

FIGURE 6: The nonevaporable water content $\left(W_{n}\right)$ detected from the TG test.

$$
\mathrm{Ca}(\mathrm{OH})_{2}[\%]=\mathrm{WL}_{\mathrm{Ca}(\mathrm{OH})_{2}}[\%] * \frac{\mathrm{MW} \mathrm{Ca}(\mathrm{OH})_{2}}{\mathrm{MWH}_{2} \mathrm{O}}
$$

where $\mathrm{WL}_{\mathrm{Ca}(\mathrm{OH})_{2}}$ is the weight loss during the dehydration of $\mathrm{CH}$ and $\mathrm{MW} \mathrm{Ca}(\mathrm{OH})_{2}$ and $\mathrm{MWH}_{2} \mathrm{O}$ are the molecular weights of $\mathrm{CH}$ and water, respectively.

Generally, Table 2 shows that the amount of $\mathrm{CH}$ decreases with increasing slag proportion mainly due to the dilution of cement by slag. However, the decrease in $\mathrm{CH}$ content is more significant with increasing SS content compared to that in the case of increasing CS content. This can be interpreted by one of two probable reasons. The first is that $\mathrm{SS}$ consumes $\mathrm{CH}$ by means of a pozzolanic reaction,
TABle 2: Calculated amount of $\mathrm{CH}$, in wt.\%.

\begin{tabular}{lccccc}
\hline & OPC & CS15 & CS30 & SS15 & SS30 \\
\hline 3 days & 15.8 & 13.9 & 11.1 & 12.4 & 10.2 \\
90 days & 18.4 & 16.9 & 13.8 & 15.5 & 12.5 \\
\hline
\end{tabular}

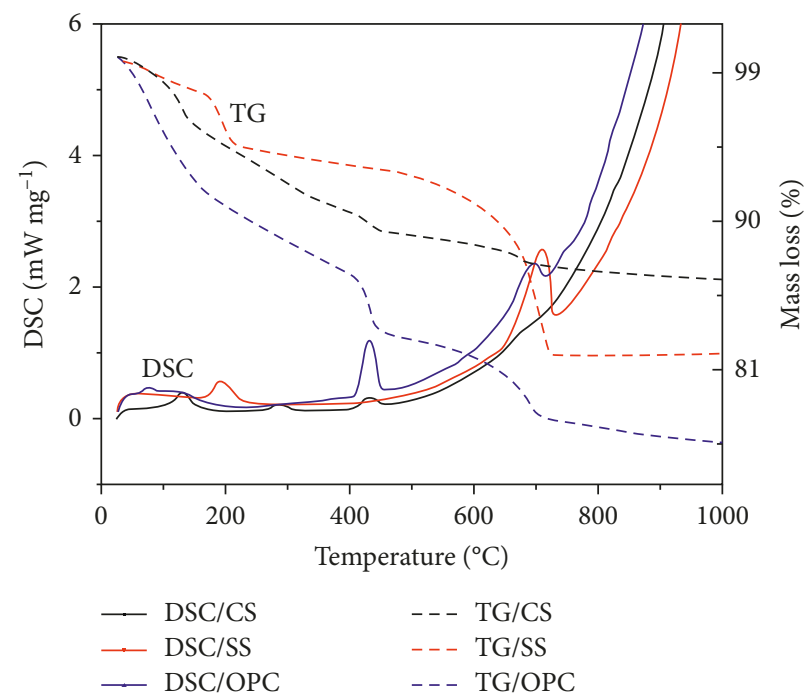

FIgURE 7: TG/DSC curves for pure OPC, CS, and SS at 90 days.

and the second is the dilution of cement by SS. For this purpose, Figure 7 shows the TG/DSC curves for pure OPC, $\mathrm{CS}$, and SS at 90 days. The peak in the temperature range $400^{\circ} \mathrm{C}$ to $550^{\circ} \mathrm{C}$ is attributed to the decomposition of $\mathrm{CH}$. It can be seen that pure SS does not produce any $\mathrm{CH}$, and its hydration products is limited to $\mathrm{C}-\mathrm{S}-\mathrm{H}$ (the temperature range of $50-200^{\circ} \mathrm{C}$ ). Furthermore, the compressive strength-discussed below-of SS15 and SS30 does not increase at later ages as observed for the common behavior 


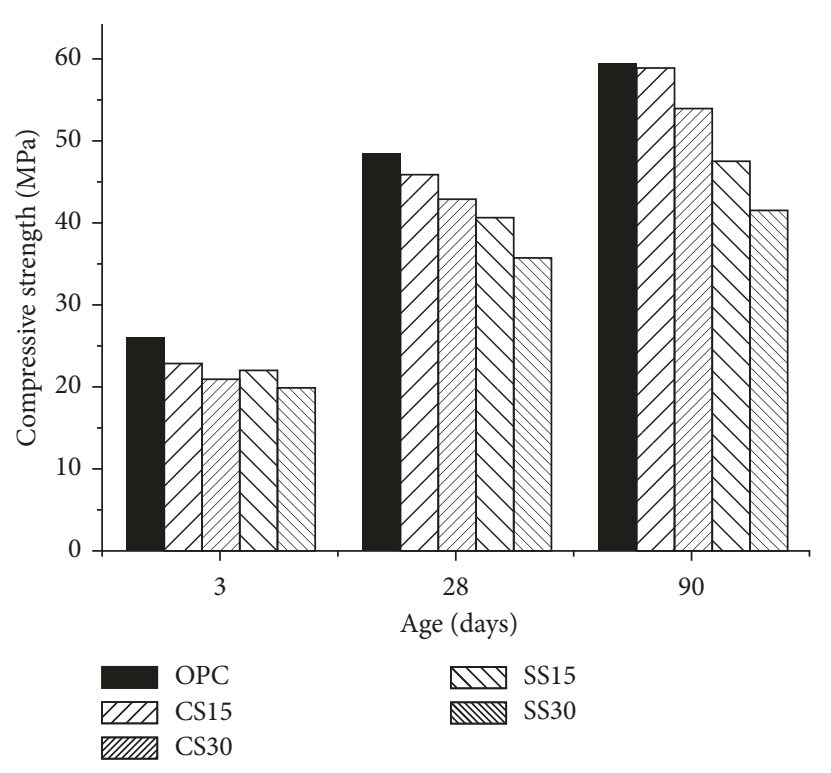

(a)

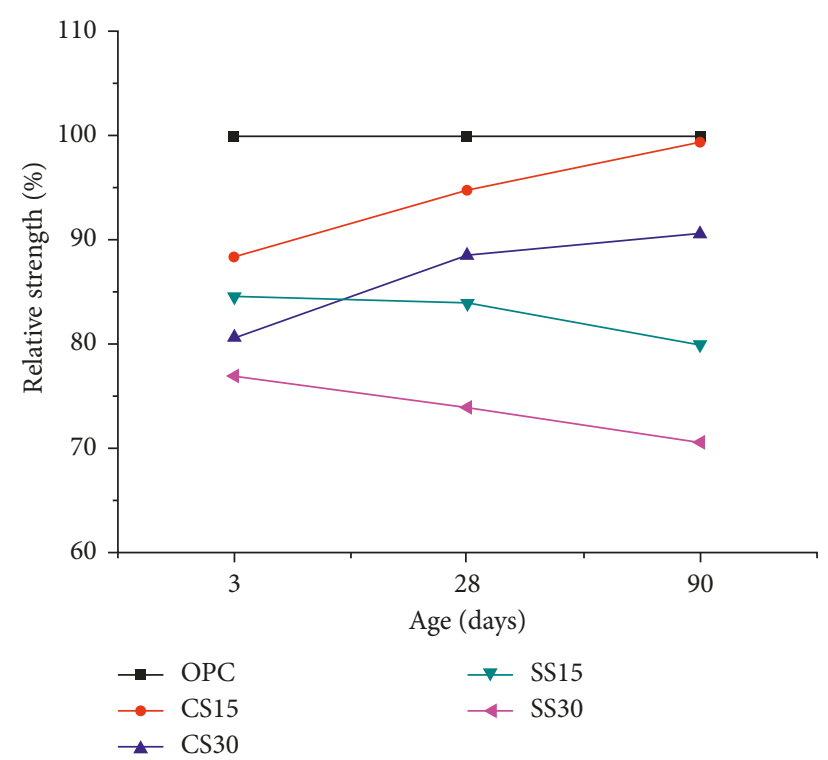

(b)

Figure 8: (a) The compressive strength and (b) the relative strength of different slag-cement ratios at 3, 28, and 90 days.

of the pozzolanic materials $[20,21]$. Therefore, it seems that there is no probability of a pozzolanic reaction occurred by SS at standard curing regimens proposed in this study. Consequently, it can be conclude that the significant decrease in $\mathrm{CH}$ content in cement-SS mix is due to the dilution of $\mathrm{CH}$ production in SS slag.

3.5. Strength. The study of compressive strength was conducted according to the Chinese National Standard GB/T50081-2002. Figure 8(a) presents the compressive strength of different slag-cement ratios at 3,28, and 90 days. To give an insight into the rates of hydration of the blended cement containing slag compared to pure cement mortar, the ratio of the strength of the slag-cement to the strength of the pure cement mortar was detected and denoted by relative strength, Figure $8(\mathrm{~b})$. It can be observed that replacing cement by steel slag (CS) or stainless steel slag (SS) tends to lower the strength at all ages due to the dilution effect on cement, which increases at higher replacement ratios of slag. However, at 3 days, the rates of strength gain of both cement-slag types are relatively approximate than at later ages, Figure $8(\mathrm{~b})$, which is consistent with hydration heat results. At the ages of 28 and 90 days, the strength increasing amplitude of CS mortar is larger than that for SS mortar at the same replacement ratio. Furthermore, the strength of CS15 is close to that of pure cement mortar at 90 days. However, at the same age, the strength of SS mortars is still much lower than that of pure cement mortar even at a low replacement ratio of $15 \%$. It is believed that stainless steel slag poses its activity at early ages, while its activity decreases gradually at later ages [22]. An opposite trend was observed for carbon steel slag, where its promoting effect on cement appears at late ages $[12,23]$. It can be concluded that blended cement containing CS has higher strength gain rate than that containing SS, especially at later ages. Furthermore, the dilution effect of steel slag on the strength of cement mortar can be neglected when its replacement ratio does not exceed $15 \%$.

3.6. SEM. SEM analyses were used to study the influence of CS and SS on the microstructure of pure cement at 3 and 90 days of curing. The SEM images of the fracture surfaces of OPC, CS30, and SS30 at 3 and 90 days are shown in Figures 9 and 10 , respectively. Comparing the two figures, it is obvious that both pure cement and cement-slag mix at $90 \mathrm{~d}$ are denser than those at $3 \mathrm{~d}$. The SEM images for OPC samples display a heterogeneous distribution of gel-like C-S-H, hexagonal plates of $\mathrm{CH}$ and needle-like ettringite crystals. Generally, for slag-cement images, the mineral particles of CS and SS are arbitrarily dispersed throughout the entire surface of hydrated cement products. Furthermore, the coarse $\mathrm{CH}$ observed in CS30 (Figure 10(b)) cannot be easily found in SS30 (Figure 10(c)).

3.7. BSE. Since BSE imaging provides a visual tool for studying the microstructure composition of cementitious materials and for differentiating different hydrates based on grey level in cement-based materials [24-26], flat polished sections were prepared for pure cement and cement-slag pastes at 90 days to be a representative for the microstructure composition of the matrix. Figure 11 shows BSE image for OPC, CS30, and SS30 hydrated for $90 \mathrm{~d}$. It can be observed that due to the high ferrite phases in both CS and SS particles compared to plain cement particles, the remained unhydrated slag particles exhibited higher atomic weight and consequently higher brightness than the hydrated phases surrounding them typically as the brightness observed for Fe-rich unreacted fly ash particles [27]. Furthermore, 


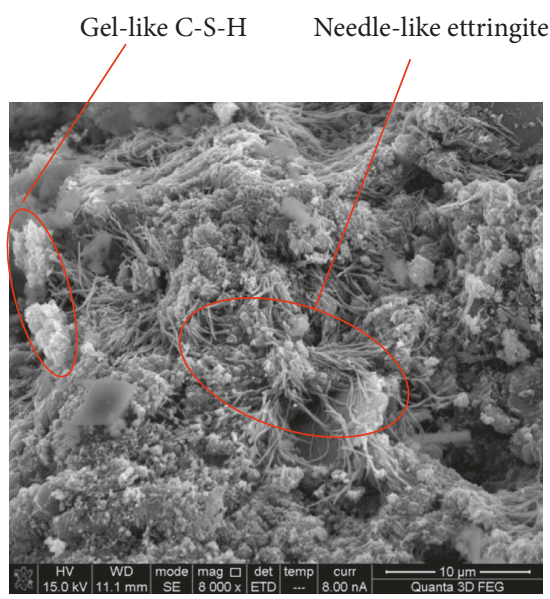

(a)

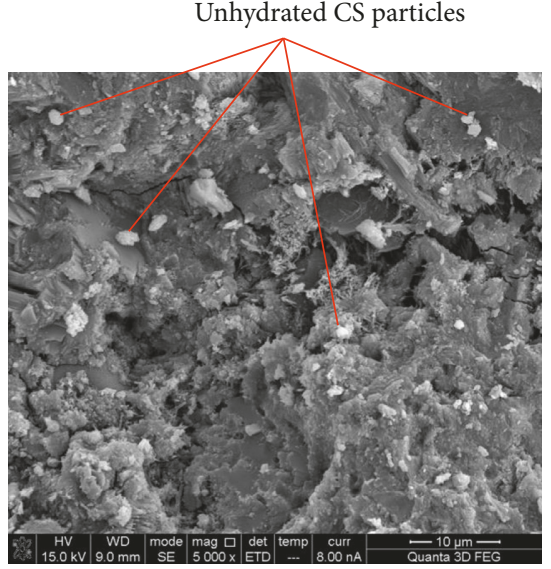

(b)

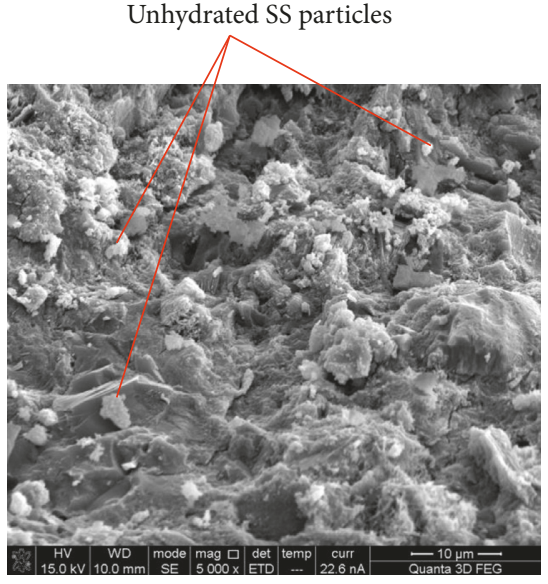

(c)

Figure 9: SEM at 3 days of (a) OPC, (b) CS30, and (c) SS30.

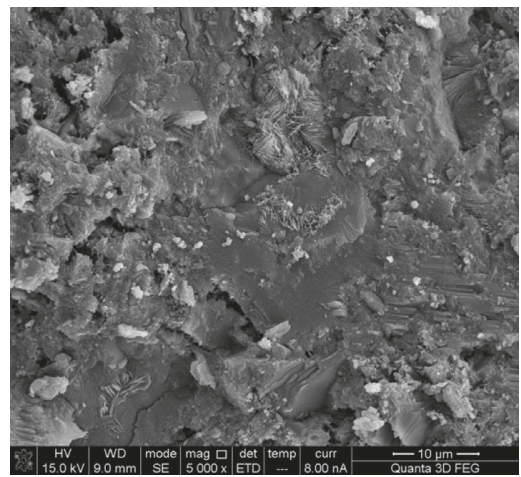

(a)

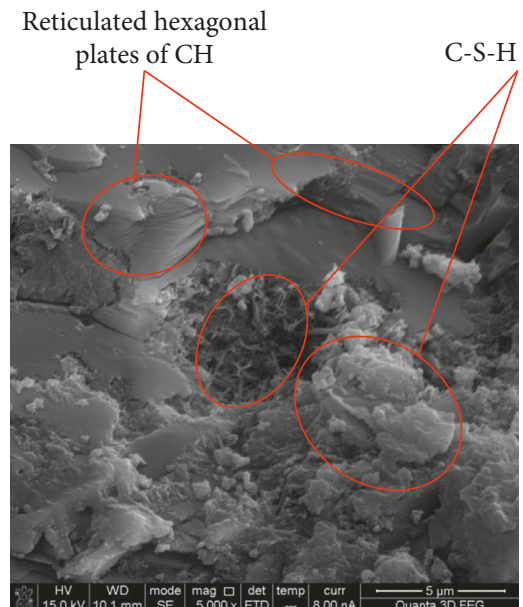

(b)

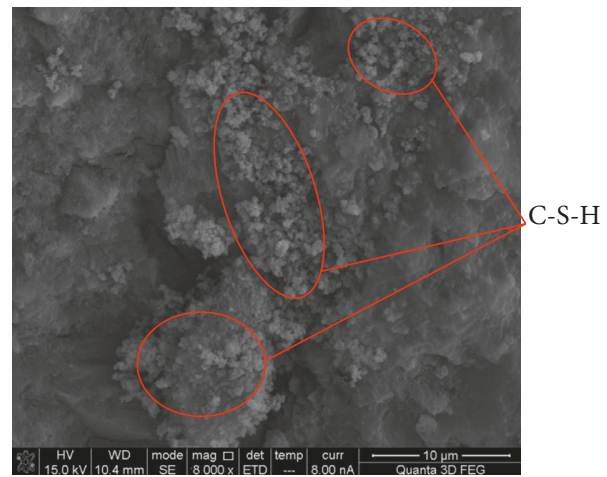

(c)

Figure 10: SEM at 90 days of (a) OPC, (b) CS30, and (c) SS30.

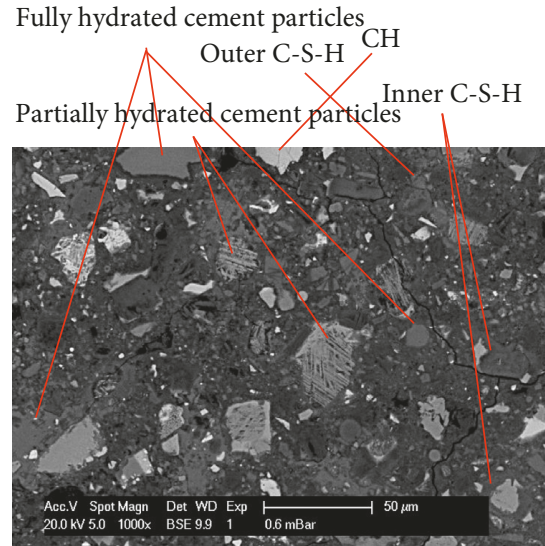

(a)

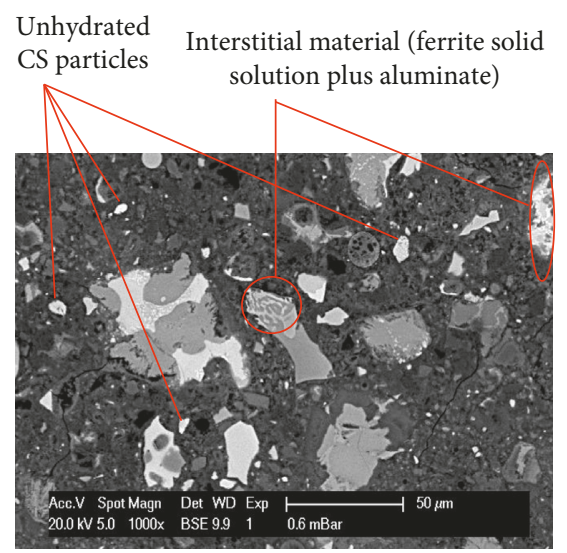

(b)

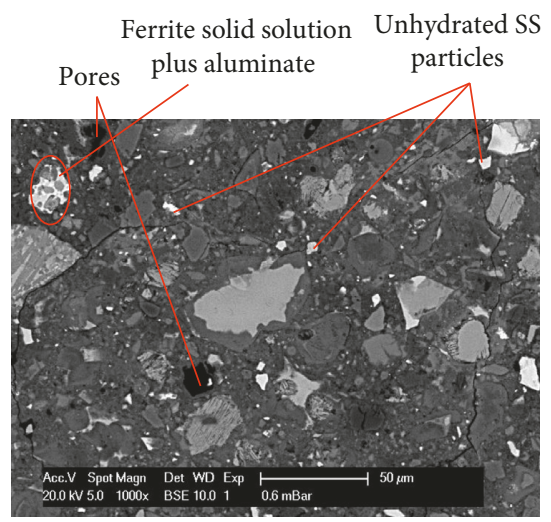

(c)

FIgURE 11: BSE image for (a) OPC, (b) CS30, and (c) SS30 hydrated for $90 \mathrm{~d}$. 


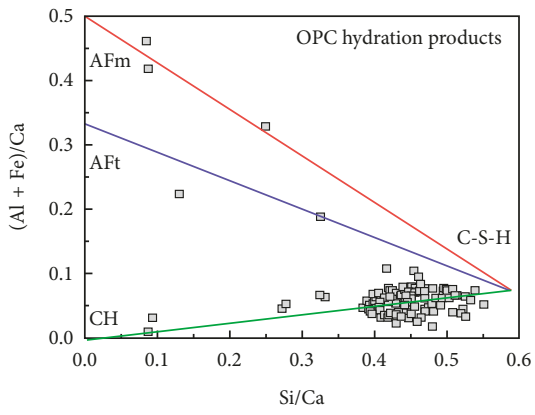

(a)

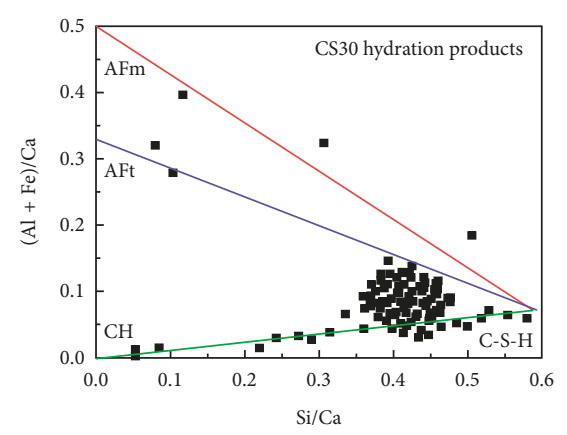

(b)

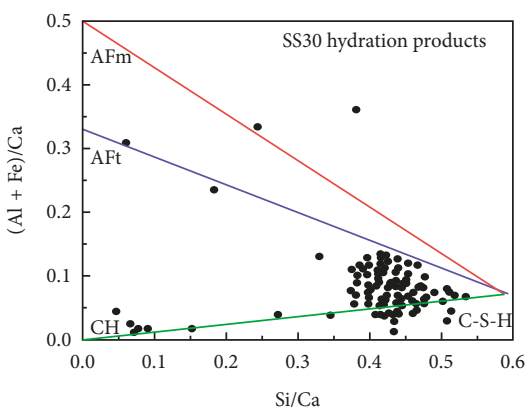

(c)

Figure 12: $\mathrm{Si} / \mathrm{Ca}$ versus $(\mathrm{Al}+\mathrm{Fe}) / \mathrm{Ca}$ atom ratio plots of SEM-EDX analyses of the hydration products present in (a) OPC, (b) CS30, and (c) SS30.

different microstructure constituents distinguished are detected based on grey level and EDX analyses, Figure 11.

To give an impression of the microstructure of the slagcement pastes, Figures 12(b) and 12(c) shows the atom ratio plots $(\mathrm{Si} / \mathrm{Ca}$ versus $(\mathrm{Al}+\mathrm{Fe}) / \mathrm{Ca})$ of SEM-EDX point analyses performed for about one hundred points on the same surfaces shown in Figures 11(b) and 11(c), respectively, compared to those for OPC at the same age of $90 \mathrm{~d}$, Figure 12(c). Accordingly, the average $\mathrm{Si} / \mathrm{Ca}$ ratio is estimated to be about $0.43(\mathrm{Ca} / \mathrm{Si}=2.33)$, consistent with the findings of Hua et al. [28] for pure cement hydrated for 90 days $(\mathrm{Ca} / \mathrm{Si}=2.34)$. However, the average $\mathrm{Si} / \mathrm{Ca}$ ratio of PCS30 and PSS30 is estimated to be $0.41(\mathrm{Ca} / \mathrm{Si}=2.44)$ and $0.45(\mathrm{Ca} / \mathrm{Si}=2.22)$, respectively. The differences in $\mathrm{Si} / \mathrm{Ca}$ ratio for pure cement than cement-slag mixes ensure that the changes occurred to the microstructure due to cement replacement by CS or SS. It can be observed that replacing cement by $\mathrm{CS}$ tends to decrease the average $\mathrm{Si} / \mathrm{Ca}$ ratio.

The high aluminate phases in CS led to the release of some aluminum in the solution with its uptake in C-S-H, essentially by the substitution of silica, which led to the reduction in the silica content in the overall hydrated matrix, and then the Si/Ca ratio decreased consequently. An opposite trend is observed for SS30 mix, where the average $\mathrm{Si} / \mathrm{Ca}$ ratio increased compared to that for pure cement. However, the increment in Si/Ca ratio in the case of SS30 seems to be caused by the lack of production of any $\mathrm{Ca}$ $(\mathrm{OH})_{2}$ from SS during its hydration (Figure 7). Furthermore, it can be observed that the shift of the average $(\mathrm{Al}+\mathrm{Fe}) / \mathrm{Ca}$ ratio plots for the cement-slag mixes compared to pure cement especially in CS30 is due to its high aluminate and ferrite phases. $\mathrm{Al}_{2} \mathrm{O}_{3}$ and $\mathrm{Fe}_{3} \mathrm{O}_{4}$ released from slag are used in increasing the $(\mathrm{Al}+\mathrm{Fe}) / \mathrm{Ca}$ ratio of the $\mathrm{C}-\mathrm{S}-\mathrm{H}$ formed from the OPC; some probably enters additional AFm or hydrogarnet phases.

\section{Conclusion}

(1) The negative effect of steel slag (CS) on the strength of cement mortar can be neglected when its replacement ratio does not exceed $15 \%$.
(2) Generally, CS- and SS-cements differ from pure cement notably in

(i) the hydration rates of the blended cement: CScement shows high strength gain rate at later ages than at early ages, oppositely the strength gain rate of SS-cement decreased at later ages;

(ii) $\mathrm{CH}$ contents, which are lowered by the dilution of the cement by slag, and it is more distinct in SS case;

(iii) the $\mathrm{Si} / \mathrm{Ca}$ ratio of the compositions of the microstructure of the slag-cement matrix: the average $\mathrm{Si} / \mathrm{Ca}$ ratio is estimated to be about 0.41 $(\mathrm{Ca} / \mathrm{Si}=2.44)$ and $0.45(\mathrm{Ca} / \mathrm{Si}=2.22)$ for $\mathrm{CS} 30$ and SS30, respectively, and differ from 0.43 $(\mathrm{Ca} / \mathrm{Si}=2.33)$ for pure cement;

(iv) the formation of hydration products from the slag; consequently, the average $(\mathrm{Al}+\mathrm{Fe}) / \mathrm{Ca}$ ratio of both of slag-cements increased compared to pure cement due to the high aluminate and ferrite phases in the slag.

\section{Data Availability}

The data used to support the findings of this study are available from the corresponding author upon request.

\section{Conflicts of Interest}

The authors declare that there are no conflicts of interest regarding the publication of this paper.

\section{Acknowledgments}

This work was supported by the National Natural Science Foundations of China (Grant nos. 51378113 and 51438003) and a Plan of Six Peak Talents in Jiangsu Province (Grant no. JZ-004) and was partly supported by the National Basic Research Program of China (973 Program, Grant no. 2015CB655102).

\section{Supplementary Materials}

Supplementary 1. The detailed description of the composition and phase analysis of raw slags used in this study can be found in the word file called (SM-1). 
Supplementary 2. The heat flow and the cumulative heat of pure cement, pure CS, and pure SS are shown in the word file called (SM-2).

Supplementary 3. Some properties of pure CS and pure SS pastes and mortars like the standard consistency, water demand ratio, and the variation of penetration depth with varying water-to-binder ratios can be found in the word file called (SM-3).

\section{References}

[1] S. J. J. van Deventer, J. Provis, P. Duxson, and D. G. Brice, "Chemical research and climate change as drivers in the commercial adoption of alkali activated materials," Waste and Biomass Valorization, vol. 1, no. 1, pp. 145-155, 2010.

[2] A. L. Riley and W. M. Mayes, "Long-term evolution of highly alkaline steel slag drainage waters," Environmental Monitoring and Assessment, vol. 187, no. 7, p. 463, 2015.

[3] H. Yi, G. Xu, H. Cheng, J. Wang, Y. Wan, and H. Chen, “An overview of utilization of steel slag," Procedia Environmental Sciences, vol. 16, pp. 791-801, 2012.

[4] S. Kourounis, S. Tsivilis, P. E. Tsakiridis, G. D. Papadimitriou, and Z. Tsibouki, "Properties and hydration of blended cements with steelmaking slag," Cement and Concrete Research, vol. 37, no. 6, pp. 815-822, 2007.

[5] C. Shi, "Steel slag-its production, processing, characteristics and cementitious properties," Journal of Materials in Civil Engineering, vol. 16, no. 3, pp. 230-236, 2004.

[6] Q. Wang, P. Yan, and G. Mi, "Effect of blended steel slagGBFS mineral admixture on hydration and strength of cement," Construction and Building Materials, vol. 35, pp. 8-14, 2012.

[7] Y.-N. Sheen, H.-Y. Wang, and T.-H. Sun, "A study of engineering properties of cement mortar with stainless steel oxidizing slag and reducing slag resource materials," Construction and Building Materials, vol. 40, pp. 239-245, 2013.

[8] C. Shi, "Characteristics and cementitious properties of ladle slag fines from steel production," Cement and Concrete Research, vol. 32, no. 3, pp. 459-462, 2002.

[9] M. Tufekci, A. Demirbas, and H. Genc, "Evaluation of steel furnace slags as cement additives," Cement and Concrete Research, vol. 27, no. 11, pp. 1713-1717, 1997.

[10] J. Li, Q. Yu, J. Wei, and T. Zhang, "Structural characteristics and hydration kinetics of modified steel slag," Cement and Concrete Research, vol. 41, no. 3, pp. 324-329, 2011.

[11] S. Liu and L. Li, "Influence of fineness on the cementitious properties of steel slag," Journal of Thermal Analysis and Calorimetry, vol. 117, no. 2, pp. 629-634, 2014.

[12] Q. Wang, P. Yan, and S. Han, "The influence of steel slag on the hydration of cement during the hydration process of complex binder," Science China Technological Sciences, vol. 54, no. 2, pp. 388-394, 2011.

[13] M. Salman, O. Cizer, Y. Pontikes, L. Vandewalle, B. Blanpain, and K. V. Balen, "Effect of curing temperatures on the alkali activation of crystalline continuous casting stainless steel slag," Construction and Building Materials, vol. 71, pp. 308-316, 2014.

[14] J. Rosales, M. Cabrera, and F. Agrela, "Effect of stainless steel slag waste as a replacement for cement in mortars. Mechanical and statistical study," Construction and Building Materials, vol. 142, pp. 444-458, 2017.

[15] L. Kriskova, P. Yiannis, C. Özlem et al., "Effect of mechanical activation on the hydraulic properties of stainless steel slags,"
Cement and Concrete Research, vol. 42, no. 6, pp. 778-788, 2012.

[16] L. Kriskova, P. Yiannis, Z. Fei et al., "Valorisation of stainless steel slags as a hydraulic binder," Acta Metallurgica Slovaca, vol. 19, no. 3, pp. 176-183, 2013.

[17] F. M. Lea, The Chemistry of Cement and Concrete, Edward Arnold, New York, NY, USA, 3rd edition, 1974.

[18] M. Castellote, C. Alonso, C. Andrade, X. Turrillas, and J. Campo, "Composition and microstructural changes of cement pastes upon heating, as studied by neutron diffraction," Cement and Concrete Research, vol. 34, no. 9, pp. 1633-1644, 2004.

[19] H. F. M. Taylor, Cement Chemistry, Thomas Telford, London, UK, 2nd edition, 1997.

[20] V. M. Malhotra and P. K. Mehta, Pozzolanic and Cementitious Materials, in Advances in Concrete Technology, vol. 1, Taylor \& Francis, Abingdon, UK, 1st edition, 1996.

[21] A. A. Ramezanianpour, Cement Replacement Materials: Properties, Durability, Sustainability, Springer, Berlin, Germany, 2016.

[22] T. Zhang, Q. Yu, J. Wei, and J. Li, "Investigation on mechanical properties, durability and micro-structural development of steel slag blended cements," Journal of Thermal Analysis and Calorimetry, vol. 110, no. 2, pp. 633-639, 2012.

[23] W. Qiang, S. M. Xiao, and Y. Jun, "Influence of classified steel slag with particle sizes smaller than $20 \mu \mathrm{m}$ on the properties of cement and concrete," Construction and Building Materials, vol. 123, pp. 601-610, 2016.

[24] S. Igarashi, M. Kawamura, and A. Watanabe, "Analysis of cement pastes and mortars by a combination of backscatterbased SEM image analysis and calculations based on the Powers model," Cement and Concrete Composites, vol. 26, no. 8, pp. 977-985, 2004.

[25] K. L. Scrivener, "Backscattered electron imaging of cementitious microstructures: understanding and quantification," Cement and Concrete Composites, vol. 26, no. 8, pp. 935-945, 2004.

[26] C. Famy, K. L. Scrivener, and A. K. Crumbie, "What causes differences of C-S-H gel grey levels in backscattered electron images?," Cement and Concrete Research, vol. 32, no. 9, pp. 1465-1471, 2002.

[27] Z. Sujing and S. Wei, "Nano-mechanical behavior of a green ultra-high performance concrete," Construction and Building Materials, vol. 63, pp. 150-160, 2014.

[28] C. Hua, Y. Gao, Y. Zhang, and Z. Lia, "Statistical nanoindentation technique in application to hardened cement pastes: influences of material microstructure and analysis method," Construction and Building Materials, vol. 113, pp. 306-316, 2016. 


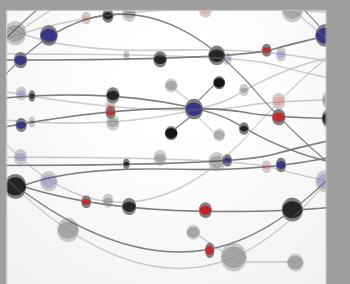

The Scientific World Journal
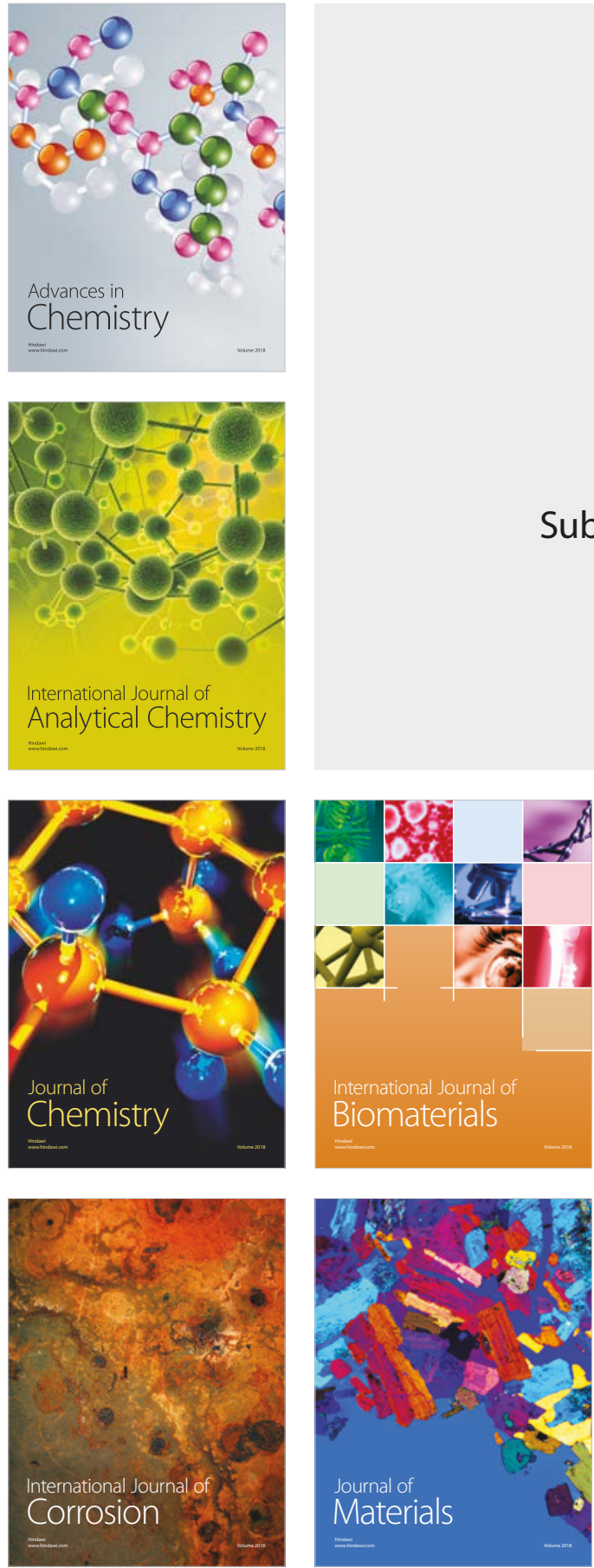

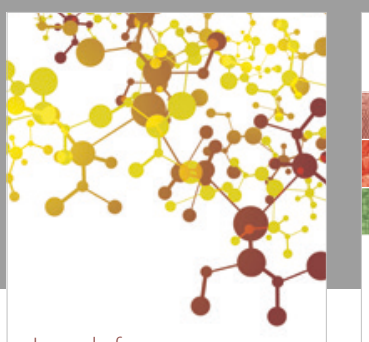

Journal of

Applied Chemistry
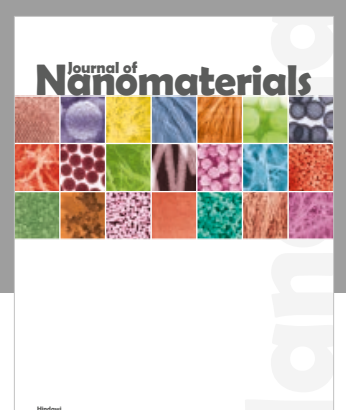

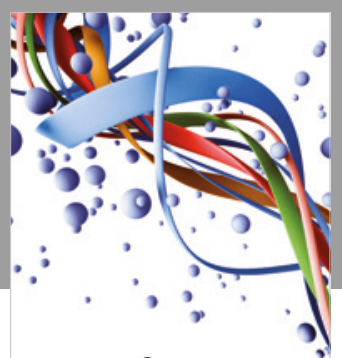

Scientifica

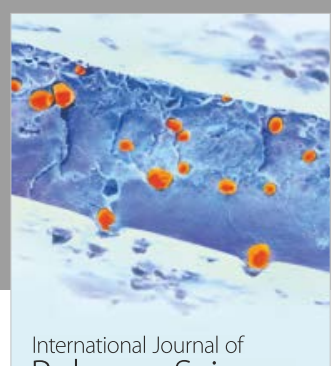

Polymer Science

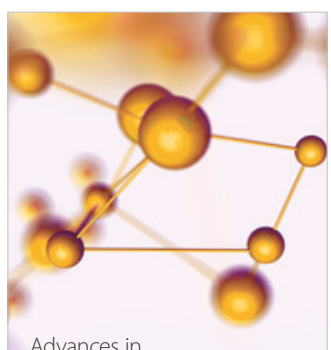

Physical Chemistry
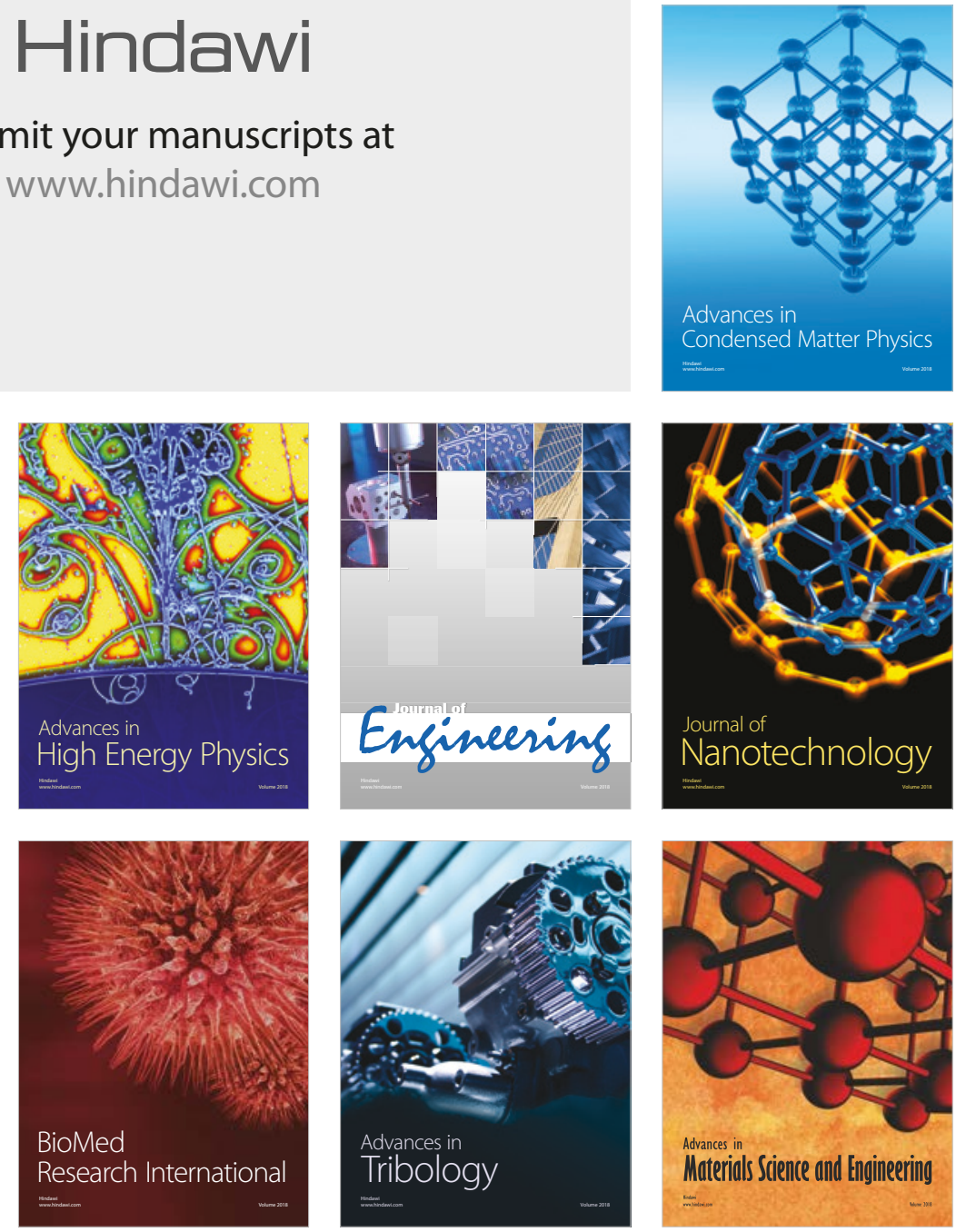